\title{
The Black Lives Matter movement and health inequalities
}

\author{
JAGRITI GANGOPADHYAY
}

\begin{abstract}
With the recent Black Lives Matter movement, existing racial inequalities in various sectors of the United States have regained prominence. Due to the pandemic, statistics on racial disparities in the health sector have been aggravated. On a related note, while the \#Black Lives Matter movement received substantial support from India's online community, deeply entrenched inequalities in terms of caste, community and gender in India's health sector need to be critically evaluated as well. This paper is an attempt to understand how the awareness generated by the Black Lives Matter movement could be an opportunity to address structural inequalities in India's own public health system.
\end{abstract}

Keywords: Black Lives Matter, racial disparities, health inequalities, race, caste, gender

The Black Lives Matter movement which has currently gained international recognition and support originated in 2013. The movement began on the social media with the death of an African-American teenager, Trayvon Martin (1). In 2014, the movement expanded into street demonstrations and gained national participation with the death of two more African-Americans, Michael Brown and Eric Garner (1). The main goal of the Black Lives Matter movement is to project non-violent forms of protest against police brutality and racial discrimination against black individuals. The main principles of this movement as stated on the Black Lives Matter website are restorative justice, empathy, diversity, collective value, reinstate the notion of care embedded in Black villages, being unapologetically Black and building a space free from sexism, misogyny, and male-centredness for Black Women (2). Some of the major policy demands of this movement have been: to end the violence against Black people; make reparation for past and continuing crimes;

Author: Jagriti Gangopadhyay (jagriti.g@manipal.edu), Assistant Professor, Manipal Centre for Humanities, Manipal Academy of Higher Education (MAHE), MCH, Planetarium Complex, Life Sciences Road, Manipal-576 104 INDIA.

To cite: Gangopadhyay J. The Black Lives Matter movement and health inequalities. Indian J Med Ethics. 2021 Jul-Sep; 6(3) NS: 234-237. DOI: 10.20529/IJME.2021.011.

Published online first on February 20, 2021.

Manuscript Editor: Rakhi Ghoshal

(c) Indian Journal of Medical Ethics 2021 divest funding from institutions that criminalise Black people, invest in the health, education and safety of Black people, ensure economic justice for all; and establish community control of laws (3).

\section{Racism as a public health crisis}

On May 25, 2020, the death of George Floyd, a 46-year-old African-American in Minneapolis, USA, while a white policeman knelt on his neck, sparked global outrage and aroused an upsurge in the Black Lives Matter (BLM) movement. Following Floyd's death, Black Lives Matter organised several rallies starting from May 30 with the slogan, "defund the police" (4). A recent poll conducted by the Pew Research Centre in June 2020 indicated that two-thirds of adults in the USA support the movement (5). Owing to these recent protests, racial inequalities have once again been brought to global prominence. However, racial disparities have always existed in US systems and institutions, and health professionals have long declared racism as a public health issue $(6,7,8,9)$. Additionally, with the rising protests, several US states such as Michigan, Nevada, Wisconsin, California and Ohio have declared racism a public health crisis (6), since it affects living conditions, income levels, access to food, education and healthcare. With Black Lives Matter garnering worldwide support, the need to recognise racism as a global public health concern becomes more urgent.

Schnall and Kern (10), in their 1981 study on hypertension in the US, found that due to unstable jobs, hypertension is high among low-income groups of African Americans. Reports published by the National Academies Press (2003; 2004) highlight that among all racial and ethnic groups in the US, African-Americans have the highest rates of morbidity and mortality $(11,12)$. For instance, in their 2004 report (12), they use the 1996 research of Lillie-Blanton et al (13), and indicate that health deficits among African-American mothers living in poverty affect the wellbeing of the infant. Similarly, another report (14) in 2014 had suggested that if State Governments engage with local community members to understand their needs, racism as a social determinant of health could be eliminated. Despite this policy recommendation, several racial inequalities persist in the US public health system. 


\section{Recent statistics: USA}

Covid-19 data on the USA, compiled by the American Public Media (APM) Research Lab (15), revealed that AfricanAmericans have died at a rate of 50.3 per 100,000 people, compared with 20.7 for white Americans, 22.9 for Latino Americans and 22.7 for Asian Americans. A recent study by Webb et al (16), indicates that African-Americans are more likely to be infected by the Covid-19 virus as they reside in poor and overcrowded neighbourhoods, work in unsafe conditions, and have limited access to healthcare.

Recent statistics from the Harvard Centre for Population and Development Studies, also showed that African Americans have higher rates of diabetes, hypertension and heart disease than other groups (17). An earlier report in 2017 by the US Department of Health and Human Services (HHS) (18) indicated that the average median household income for African Americans was $\$ 40,165$, compared with $\$ 65,845$ for white households. Additionally, 22.9\% of African Americans lived at the poverty level, compared with $9.6 \%$ of whites, with an unemployment rate of $9.5 \%$ for African Americans compared to $4.2 \%$ for whites. Despite a lower annual household income, African Americans ended up spending a higher share of their income on medical care, $16.5 \%$ in comparison to $12.2 \%$ for whites (18). These distressing numbers suggest that institutionalised racial inequalities have always persisted in the USA, notwithstanding the Civil Rights Act of 1964 and the pandemic as well as the BLM Movement have only exposed these inequalities further.

\section{Health inequalities in India}

With the death of George Floyd, \#Black Lives Matter began trending on several social media platforms and garnered significant solidarity among India's online community. Similar to racial inequalities in the US, is the discrimination based on caste, gender and religion which is ingrained in the Indian public healthcare system. Jean Dreze and Amartya Sen in their seminal book, An Uncertain Glory: India and its Contradictions, published in 2013 (19), highlighted how inadequate access to basic facilities such as education and medical care among lower-income groups, women, lower caste groups, and tribal communities have hampered India's overall growth. In particular, Dreze and Sen (19) recommend equal representation of all categories and communities at the policy level to accelerate India's development goals.

Drawing from various sources of secondary data, this paper points out the different forms of health disparities such as a) lack of access to health centres, b) unequal enrolment in medical education and in c) healthcare spending. However, it is important to note that all the disparities may not accrue to all the disadvantaged groups (tribal communities/Muslims/ rural women/transgender).

Highlighting the poor health status of tribal communities in India, a 2018 report submitted by the Abhay Bang Committee (20), indicated that the health condition of the tribal community in India is the worst as compared with other social groups. The report further added that the tribal community which constitutes $8.6 \%$ of India's population, is suffering from a triple burden of disease. Due to malnutrition and lack of resources, malaria and tuberculosis continue to be rampant among the tribal people in India. On the other hand, with rapid urbanisation diseases such as cancer, hypertension and diabetes have also increased among the tribal population. Finally, the report pointed out that owing to lack of access and geographical isolation, mental health issues have also emerged among the tribal community (20). Another 2015 study by George (21) illustrated that tribal communities of India continue to be isolated, emphasised by the fact that no primary health centres or community health centres were built from 2006 to 2014 in the tribal areas of India.

Apart from lack of access to health centres and resources as mentioned above, lower caste groups and tribal communities are also under-represented in medical education in India. For instance, data from the All India Survey of Higher Education for 2018-19 (22), under the Human Resources Development ministry, found that, in the last seven years, the enrolment at 43 medical courses was only $13.42 \%$ for Scheduled Castes, and $4.95 \%$ for Scheduled Tribes in the entire period, whereas the quota for Scheduled Castes is $15 \%$ per year and that of Scheduled Tribes is $7.5 \%$ per year.

The Sachar Committee, in its 2006 Report on the social, economic and educational status of the Muslim community in India (23), indicated that $40 \%$ of villages with a Muslim majority population in India do not have any medical facilities. Additionally, the Sachar Committee (23) found that the representation of Muslim students enrolled in the top medical colleges of India is only 4\%. Another 2014 report by Contractor and Barai on the Health of Muslims in Maharashtra (24), highlighted the dearth of health infrastructure in the highly populated Muslim areas of the State.

Based on the 71st round of the National Sample Survey Organization 2014, Ladusingh et al (25) found in 2018 that married women in rural India have to cope with communicable, non-communicable, and reproductive health diseases. Despite, this triple burden of disease, women in rural areas spend much less on their health.

Shedding light on the situation of the transgender community in India, Amnesty International recently pointed out that none of the relief packages announced during the nationwide lockdown by the Government of India to tackle Covid-19 included the transgender community (26).

\section{Discrimination in healthcare facilities}

A study on Dalit construction workers highlighted how Dalits in India face unequal treatment by the medical staff in health centres (27). Another study conducted by Shaikh et al 
(28) found that lower caste groups have to wait longer to be attended in private facilities. Similar to caste-based inequality, studies have also indicated how women belonging to lower income and caste groups in India have often had to bear the brunt of unsafe abortions (29), and of the surreptitious use of new reproductive technologies on their bodies (30). Highlighting the discriminatory behaviour of the medical community towards the transgender community in India, Ming et al (31), suggest that despite receiving legal recognition, transgender people continue to be subjected to psychological and verbal abuse by doctors and other medical staff (31).

Besides their lack of access to healthcare, women and lower caste groups have often been coerced into unethical clinical trials as well. In line with the USA, where scientists performed various unethical medical experiments on Africans and African Americans (32), lower caste groups and women belonging to lower income groups in India $(33,34)$ have also been subjected to clinical trials without following proper rules of informed consent. Owing to their lack of access to good quality healthcare, recruitment of participants from these marginalised groups becomes easier for the pharmaceutical companies conducting the clinical trials (34).

Sunder Rajan in his 2006 book titled, Biocapital (35), argued that increasingly, contract research organisations (CRO) are responsible for conducting clinical trials outsourced from the West. Specifically, Rajan illustrated how unemployed mill workers in India became human subjects for new chemical substances in the experimental stage, while the tested drugs were sent to North America. In particular, Rajan's work argues how the capitalist pharmaceutical companies, exploit marginalised and poverty ridden communities for their own interests (35). Similar to Rajan's work, several news reports have highlighted how lower caste women and men are often subjected to unfair clinical practices by the pharmaceutical companies. For instance lower caste women from Madhya Pradesh (33) and lower caste men from Rajasthan (34) were made to consume pills without proper information regarding the drugs being revealed to them. Similarly, women in India, have often been coerced into sterilisation without their informed consent (36).

\section{Intersectionality}

The BLM movement, as well as a summary of the secondary data and studies conducted by scholars in the US and India, reveal the various forms of structured inequalities embedded in the public health system of both countries. However, to achieve social justice, an intersectional approach that recognises the intersections between the inequalities faced by the marginalised communities needs to be adopted. Scholars of medical sociology and sociology of health and medicine have used the Marxist and the feminist frameworks and argued that race, caste, class and gender are the main axes of stratification in the health sector. Patricia Hill Collins and Simon Bilge in their book Intersectionality
(37) argued that it is important to recognise the intersections between race, class and gender to address institutionalised inequality. Similarly, Gita Sen and Aditi lyer in their studies of 2009, 2012, and 2016 (38, 39, 40), examining intersectionality in India, highlighted the significance of gender in determining health status across class groups. Through their studies, Sen and lyer $(38,39,40)$, demonstrate the similarities between non-poor women and poor women. The non-poor women faced restrictions on mobility, with no control over decisions related to their education, marriage and childbearing and no recognition of their health needs during pregnancy or illness. On the other hand, poor women stopped their treatment prematurely, while poor men used household resources or took loans to continue treatment for their long-term illnesses. Likewise, Ravindran (41), suggests that the intersectionality-informed approaches require policymakers to take note of multiple identities and diversity within the single axis of social stratification such as class, caste and gender. For instance, cash transfers for institutional deliveries for women living below the poverty line failed to reach the poorest women among the Scheduled Castes (41).

\section{The way forward}

With the pandemic uncovering India's poor healthcare system, Dipankar Gupta in a recent article (42) critiqued privatisation of medical care and insisted on a Universal Health Plan for India. Though a Universal Health Plan seems desirable, it may not necessarily remove health inequities. For instance, according to the Report of the Working Group on Inequalities, 1980, in Health (43) published by the United Kingdom Department of Health and Social Security (also referred as the Black Report) found that socio-economic inequalities were the main cause for overall mortality and widening health inequities in Britain. In particular, the report showed that in spite of the establishment of the National Health Service in 1948, ill-health and death continued to be unequally distributed in Britain. As the National Health Service did not take into account social inequalities such as diet, income, housing, education, conditions of work and employment influencing health, ill-health and mortality rates varied across the British population (43). Another report published in 2018 by the Centre for Reproductive Rights, Geneva, found that Universal Healthcare in Europe excludes the most vulnerable and marginalised sections of society. For instance, undocumented migrant pregnant women (a vulnerable subgroup) in most European countries are prevented from accessing free and subsidised care (44). Hence, it may be suggested that before implementing Universal Healthcare, it is important to take note of the health needs of the various sub-categories and diversities within the main social determinants of health such as race, caste, gender, nationality, religion and ethnicity.

Focussing on the social determinants of health could help identify the inherent health inequities in India. This is a potential research area and future studies in India could use 
the intersectionality approach, to focus on the various health inequities embedded in the public healthcare system of India.

\section{References}

1. Day E. \#Black Lives Matter: the birth of a new civil rights movement. Guardian. 2015 Jul 19[cited 2020 Nov 11]. Available from: https:// www.theguardian.com/world/2015/jul/19/blacklivesmatter-birthcivil-rights-movement

2. Black Lives Matter website. 2013[cited 2020 Nov 11] Available from: https://blacklivesmatter.com/

3. Lee T. Black Lives Matter releases policy agenda. NBC News. 2016 Aug 1[cited 2020 Nov 12]. Available from: https:// www.nbcnews.com/news/us-news/black-lives-matter-releasespolicy-agenda-n620966

4. Andrew S. There is a growing call to defund the police. Here's what it means. CNN News. 2020 Jun 17[cited 2020 Nov 12]. Available from: https://edition.cnn.com/2020/06/06/us/what-is-defund-police-trnd/ index.html

5. Parker K, Horowitz JM, Anderson M. . Amid protests, majorities across racial and ethnic groups express support for the Black Lives Matter Movement. Pew Research Centre. 2020 Jun12 [cited 2020 Nov 12]. Accessed at https://www.pewsocialtrends.org/2020/06/12/amidprotests-majorities-across-racial-and-ethnic-groups-expresssupport-for-the-black-lives-matter-movement/

6. Kaur H, Mitchell S. States are calling racism a public health crisis. Here's what it means. CNN Health. 2020 Aug 14[cited 2020 Nov 11]. Available from: https://edition.cnn.com/2020/08/14/health/statesracism-public-health-crisis-trnd/index.html

7. Jones CP. Invited commentary: "Race," racism, and the practice of epidemiology. Am J Epidemiol. 2001 Aug 15; 154(4), 299-304.

8. Krieger N. Does racism harm health? Did child abuse exist before 1962? On explicit questions critical science and current controversies: An ecosocial perspective. Am J Public Health. 2003 Feb; 93(2), 194-199.

9. García, JJL. Sharif, M.Z. Black Lives Matter: A commentary on racism and public health. Am J Public Health. 2015 Jun; 105(8), e27-e30. https://doi.org/10.2105/AJPH.2015.302706

10. Schnall, PL. Kern, R.. Hypertension in American Society: An Introduction to Historical Materialist Epidemiology, in P. Conrad and R. Kern (eds), The Sociology of Health and Illness. (pp: 97-122). 1981 Jan. New York: St Martin's Press.

11. Institute of Medicine. Unequal Treatment: Confronting Racial and Ethnic Disparities in Health Care. Washington, DC: The National Academies Press; 2003. https://doi.org/10.17226/12875.

12. National Research Council. Measuring Racial Discrimination. Washington, DC:The National Academies Press; 2004. https://doi.org/ $10.17226 / 10887$.

13. Lillie-Blanton M, Parson PE, Gayle H, Dievler A. Racial differences in health: Not just black and white, but shades of gray. Annual Review of Public Health, 1996 May; 17:411-448.

14. Institute of Medicine. Supporting a Movement for Health and Health Equity: Lessons from Social Movements: Workshop Summary. Washington, DC: The National Academies Press; 2014. https://doi.org/ $10.17226 / 18751$

15. American Public Media Lab. The Colour of Coronavirus. 2020[cited 2020 Nov 11]. Accessed from https://www.apmresearchlab.org/ covid/deaths-by-race

16. Webb HM, Nápoles AM, Pérez-Stable EJ. COVID-19 and Racial/Ethnic Disparities. JAMA. 2020 Jun; 323(24):2466-2467. doi:10.1001/jama. 2020.8598

17. Bassett MT, Chen JT, Kreiger N. The unequal toll of COVID-19 mortality by age in the United States: Quantifying racial/ethnic disparities. Harvard Centre for Population and Development Studies Working Paper. 2020 Jun; 9(3).

18. Department of Health and Human Services (HHS) Office of Minority Health, USA 2017[cited 2020 Nov 11] Accessed from https:// www.minorityhealth.hhs.gov/omh/browse.aspx?|v|=3\&|vlid=61

19. Dreze J, Sen A. An Uncertain Glory. India and its Contradictions. 2013 Jun; United Kingdom: Allen Lane.

20. Ministry of Tribal Affairs. Tribal Health in India: Bridging the gap and a roadmap for the future (also known as the Abhay Bang Committee report). 2018 Aug 9[cited 2020 Nov 12]. Available from: https:// www.nhm.gov.in/nhm_components/tribal_report/ Executive_Summary.pdf
21. George S. Caste and Care: Is Indian Healthcare Delivery System Favourable for Dalits? ISEC Working Paper 350. Bengaluru: Institute for Social and Economic Change; 2015.

22. Ministry of Human Resource Development. All India Survey of Higher Education. 2019 Aug [cited 2020 Nov 12]. Available from: http:// aishe.nic.in/aishe/viewDocument.action?documentld=262

23. Government of India. Social, Economic and Education Status of the Muslim Community in India -A report (also known as the Sachar Committee Report). Prime Health of Muslims in Maharashtra / 58 Ministers High Level Committee, 2006 Nov 17[cited 2020 Nov 11]. Available from http://www.minorityaffairs.gov.in/sachar

24. Contractor S, Barai - Jaitly T. Health of Muslims in Maharashtra. 2014 .Mumbai: CEHAT. Available from http://www.cehat.org/ uploads/files/R\%2092\%20Health\%20of\%20Muslims.pdf

25. Ladusingh L, Mohanty SK, Thangjam M. Triple burden of disease and out of pocket healthcare expenditure of women in India. PLOS ONE, 2018 May 10; 13(5): e0196835. https://doi.org/10.1371/journal.pone. 0196835

26. Amnesty International India. As the World Comes Together, India's Transgender Community Fights COVID-19 Alone. 2020 Apr 1[cited 2020 Nov 12]. Available from https://amnesty.org.in/as-the-worldcomes-together-indias-transgender-community-fights-covid-19alone/

27. Priya R. Dalit perceptions of health. Seminar. 1995 Apr; 428:15-19.

28. Shaikh M, Miraldo M, Renner, AT. Waiting time at health facilities and social class: Evidence from the Indian caste system. PloS one, 2018 Oct 15; 13(10), e0205641. https://doi.org/10.1371/journal.pone. 0205641

29. Tharu S, Niranjana T. Problems for a Contemporary Theory of Gender, In: Chaudhuri M (ed), Feminism in India. New Delhi: Kali for Women; 2004. pp: 259-70.

30. Pandey A. Wombs in labour: transnational commercial surrogacy in India. New York: Columbia University Press; 2014.

31. Ming LC, Hadi MA, Khan TM. Transgender health in India and Pakistan. Lancet. 2016 Nov 26; 388(10060):2601-02. doi:10.1016/ S0140-6736(16)32222-X

32. Washington HA. Medical Apartheid. New York: Anchor Books; 2006.

33. Lloyd-Roberts $S$. Have India's poor become human guinea pigs? $B B C$ News. 2012 Nov 1 [cited 2020 Nov 10]. Available from: https://www.bbc.com/news/magazine-20136654

34. Dixit N. Churu Drug Trials: Four months on, Dalit victims report severe damage to health and caste-based harassment. Caravan. 2018 Oct 23[cited 2020 Nov 12]. Available from https:// caravanmagazine.in/health-and-education/churu-drug-trials-fourmonths-on-dalit-victims-report-severe-damage-to-health-andcaste-based-harassment

35. Rajan S. Biocapital. North Carolina: Duke University Press, 2006.

36. Pandey G. Why do Indian women go to sterilisation camps? $B B C$. 2014 Nov 11. [cited 2020 Nov 11]. Available from https:// www.bbc.com/news/world-asia-india-29999883

37. Collins PH., Bilge S. Intersectionality. Malden: Polity Press; 2016

38. Sen G, lyer A, Mukherjee C. A methodology to analyse the intersections of social inequalities in health. J Human Dev Capabil. 2009 Jul 22; 10:397-415

39. Sen G, lyer A. Who gains, who loses and how: leveraging gender and class intersections to secure health entitlements. Soc Sci Med. 2012 Jun; 74(11):1802-11. doi:10.1016/j.socscimed.2011.05.035

40. Sen $G$, lyer $A$. The mechanisms of intersectioning social inequalities in health. BMJ Glob Health, 2016; 1(Suppl 1): A35-6.

41. Ravindran TKS. Commentary: Beyond the socioeconomic. In: The Health Gap: gender and intersectionality, Int J Epidemiol. 2017 Sep 1; 46(4): 1321- 2. Doi: https://doi.org/10.1093/ije/dyx165

42. Gupta D. Falling sick together: Covid-19 pandemic has immensely boosted the case for Universal Healthcare. Times of India. 2020 Apr 29 [cited 2020 Nov 11]. Available from from https:// timesofindia.indiatimes.com/blogs/toi-edit-page/falling-sicktogether-covid-19-pandemic-has-immensely-boosted-the-case-foruniversal-healthcare/

43. Department of Health and Social Security, UK. Inequalities in Health. Report of a Research Working Group. London: DHSS; 1980.

44. Centre for Reproductive Rights. Perilous Pregnancies: Barriers in Access to Affordable Maternal Health Care for Undocumented Migrant Women in the European Union. 2018 Sep 27[cited 2020 Nov 12]. Available from https://tbinternet.ohchr.org/Treaties/CERD/ Shared\%20Documents/POL/INT_CERD_NGO_POL_35583_E.pdf 